\title{
EL HISTORICISMO ARTÍSTICO COMO HERRAMIENTA DE LEGITIMACIÓN POLÍTICA Y RELIGIOSA. ANTONIO LÓPEZ FERREIRO Y LA SEGUNDA INVENTIO DEL APÓSTOL SANTIAGO EN COMPOSTELA
}

\author{
POR \\ ANA PÉREZ VARELA ${ }^{1}$ \\ Universidade de Santiago de Compostela
}

\section{RESUMEN}

En este artículo pretendemos recoger algunos de los parámetros ideológicos que llevaron a López Ferreiro a reconstruir la cripta de la catedral de Santiago haciendo uso del historicismo para legitimar los restos sagrados recuperados tras la segunda inventio, en un contexto de entusiasta actividad científica e historiográfica en el que se acentuó la polémica sobre la autenticidad de las reliquias del Apóstol. Además, este suceso se enmarca en las pretensiones del arzobispo Payá y Rico, abiertamente enfrentado con López Ferreiro y su cabildo. Nuestra reflexión recoge las fuentes y publicaciones creadas por el propio fabriquero, los documentos relativos a las obras consultados en el archivo de la catedral de Santiago, y un repaso de la bibliografía jacobea. Trataremos de demostrar que el diseño de cada elemento orquestado por el fabriquero persigue la identificación del objeto material con una idea cultural e histórica que evoca un poder y una religiosidad concreta basadas en los siglos I y XII.

PALABRAS CLAVE: cripta; neorrománico; inventio; Santiago Apóstol; López Ferreiro

\section{THE ARTISTIC HISTORICISM AS A MECHANISM OF POLITICAL AND RELIGIOUS LEGITIMACY. ANTONIO LÓPEZ FERREIRO AND THE SECOND INVENTIO OF THE APOSTLE SAINT JAMES IN COMPOSTELA}

\section{ABSTRACT}

In this paper we aim to collect some of the ideological parameters that led López Ferreiro to reconstruct the crypt of the Cathedral of Santiago making use of the historicist style to legitimate the holy remains recovered in the second inventio, within a context of enthusiastic scientific and historiographic activity, when de polemic about the authenticity of the relics of the Apostle accentuated. In addition, this event is part of the pretensions of Archbishop Payá y Rico, openly confronted with López Ferreiro and his lobby. Our reflection presents the sources and publications created by the own churchwarden, as well as the documents related to the project, consulted in the archive of the Cathedral of Santiago, and the subsequent bibliography. We will try to demonstrate that each design of each element orchestrated by the churchwarden is pursuing the identification of the material object with a cultural and historical idea which evocates a particular power and religiosity based on the first and twelfth century. KEY WORDS: crypt; Neo-Romanesque; invention; Santiago Apostle; López Ferreiro.

Cómo CITAR ESTE ARTículo / CitATION: Pérez Varela, Ana. 2021. «El historicismo artístico como herramienta de legitimación política y religiosa. Antonio López Ferreiro y la segunda inventio del apóstol Santiago en Compostela». Hispania Sacra LXXIII, 148: 561-574. https://doi.org/10.3989/hs.2021.043

Recibido/Received 28-01-2020

Aceptado/Accepted 28-08-2020 


\section{EL PUNTO DE PARTIDA: LA SEGUNDA INVENTIO (1879) ${ }^{2}$}

Santiago de Compostela nació a partir de un hecho extraordinario: la inventio de los huesos apostólicos hallados en los albores del siglo IX. ${ }^{3}$ El suceso supuso el pilar fundamental sobre el que se construyó no sólo un santuario de peregrinación, sino una población que germinó en torno a este núcleo sagrado, convirtiéndose en uno los epicentros de la cristiandad. La inventio nació al calor de la situación histórica a la que había llegado el reino astur a finales del siglo VIII. En palabras de Singul Lorenzo (2004, 102), en este momento "se produce una suerte de fusión entre la tradición jacobea de la evangelización de Hispania y la idea del patronazgo apostólico del reino. Esta unión conceptual, de resultados fecundos en el futuro, revertirá en una entrega en las devociones del pueblo y en la difusión del culto a Santiago». La instrumentalización del culto a Santiago, ejemplificada en el himno $O$ dei verbum patris atribuido a Beato de Liébana (ca. 786), pasó por convertir a Santiago en un intercesor de la joven monarquía galaicoasturiana o astur-leonesa (Herbers 2006, 31-32).

El carácter milagroso y legendario del hallazgo motivó la discusión más polémica de la historia compostelana: la autenticidad o no de los restos. Ésta se vio acentuada tras la segunda inventio o reaparición de las reliquias jacobeas, perdidas en el siglo XVI en el subsuelo catedralicio. En 1589 el arzobispo Juan de Sanclemente (15871602) había ocultado los huesos en la catedral por miedo a los saqueos de las tropas de Francis Drake, que habían desembarcado en A Coruña, y había enviado el resto de reliquias a la catedral de Ourense para protegerlas, ${ }^{4}$ habiendo solicitado además a Felipe II que mandase «enviar xente de socorro porque este santo cuerpo del apóstol por nuestros pecados no sea profanado por estos bárbaros hereges» (cfr. García Iglesias 2013, 26). Los restos jacobeos quedaron perdidos en un lugar desconocido de la fábrica, supuestamente ocultos bajo la capilla mayor. La imposibilidad de contemplar un sarcófago o cualquier indicio material fue paulatinamente perjudicando la credibilidad de la presencia del cuerpo del Apóstol y la catedral se convirtió así en un centro espiritual al que acudían

go.

Abreviaturas utilizadas: ACS = Archivo de la catedral de Santia-

Las primeras descripciones de la inventio que han llegado a nosotros proceden del Acta de consagración de la basílica de Alfonso III (899); la Concordia de Anteltares entre Diego Peláez y el abad Fagildo (1077); el Chronicon iriense (siglos X-XI); la Historia compostelana (1107-1140) y el Liber Sancti lacobi (ca. 1140). Las descripciones más circunstanciadas del suceso las encontramos en el Libro dos Cambeadores y la Crónica de Santa María de Iria. Esta última está datada en 1444 , mientras que el texto de los cambeadores resulta polémico, ya que fue fechado por López Ferreiro muy tempranamente, de forma coetánea a la fundación de la ciudad, y sin embargo, el libro fue conocido por él y otros historiadores mediante una copia del XVII.

4 Las actas capitulares ourensanas recogen: «Llegó un correo del Sr. Arçobispo de Santiago y traxo una letra suya que auisa al cabildo [de Ourense] del aprieto y gran peligro en que está la Coruña y lo que se espera en Santiago, y que por esta causa inbiaba la mayor parte de las reliquias de aquella Sta iglesia y pide sean puesta en parte segura». Las actas compostelanas no recogen esta intención, pero si certifican que el 12 de mayo las reliquias ya estaban en Ourense (López Ferreiro, VIII: 311). miles de peregrinos a venerar unas reliquias que de las cuales no se conocía su paradero. ${ }^{5}$

El fenómeno de las peregrinaciones había experimentado un gran declive, bien patente desde principios del siglo XIX y anclado en las medidas de la reforma de la iglesia y los ataques de los gobiernos liberales (cfr. Villares Paz 2004, 12). Aunque bien es cierto que en las décadas finales del siglo XIX nacieron otras formas de religiosidad como resultado del proceso de restauración del papel social y político de la Iglesia en España después del Sexenio Revolucionario (1868-1874) y en consecuencia, comenzó a recuperarse con fuerza la cultura de peregrinación a nuevos santuarios en torno a reliquias o milagros, tales como Montserrat, Covadonga o el Pilar en Zaragoza, apareciendo incluso nuevos focos como Lourdes (Villares Paz 2004, 14). Pero, ¿quién iba a peregrinar a una catedral sin reliquias?

La Iglesia compostelana emprendió en 1878 una expedición arqueológica que reconociese el edículo supuestamente oculto bajo el altar y recuperase los restos de Santiago. En ella entraron en juego dos personalidades fundamentales como fueron el fabriquero e historiador López Ferreiro (canónigo entre 1871 y 1910) y el arzobispo Payá y Rico (prelado entre 1874-1886), militantes convencidos de tendencias muy distintas, y por lo tanto, con diferentes intenciones. Debemos llevar a cabo la interpretación del fenómeno de la segunda inventio sin perder de vista su contexto histórico, marcado por los flecos de una lucha de dos fuertes poderes contrapuestos.

Por un lado, nos encontramos con un anquilosado cabildo, abiertamente carlista, liderado por López Ferreiro. Su enorme contribución a la historiografía gallega se basa en un perfil tradicionalista que transparenta las necesidades de legitimación ideológica de un grupo social concreto como es el clero (Villares Paz 1979, 429). Su método huye conscientemente del "hipercriticismo», tendencia que niega y desprecia toda noticia que no tenga apoyo documental, postura tomada de forma sistemática por los bolandistas y Duchesne. Para él la tradición es «la pátina que reviste el acontecimiento y lo preserva», y es la historiografía la que debe purificar el dato de su envoltura forjada por la tradición a lo largo de los siglos (Barreiro Fernández 1978, 218-219). De hecho, el historiador criticó abiertamente a Duchesne por el hecho de que sólo atendiese al hecho tangible, a lo que se sabe fehacientemente que ocurrió, y no al contexto, que puede darnos muchas más pistas sobre los hechos en sí (Sánchez Sánchez 2010, 513-514). Su evidente "fervor apologético» por la iglesia compostelana, tal y como lo define Villares Paz $(1979,436)$, hace inevitable pensar que su aceptación sin cuestionamiento de los principios teológicos de la Iglesia limitó su libertad como intelectual (Barreiro Fernández 1978, 221). En el proceso de recuperación de la cripta debemos resaltar su formación como arqueólogo, estudiada entre

5 Pese a que las guías y obras descriptivas de la época surgidas del círculo catedralicio como las de López Ferreiro (1877), Villaamil y Castro $(1866,73-74)$ o Zepedano y Carnero (1870, 20-27), afirmaban la existencia del cuerpo, los viajeros extranjeros se mostraban recelosos. Cuando Borrow (1996, 316-317) realizó su viaje a Santiago en 1837, su desconfianza ante el asunto lo llevó a preguntar la opinión de los compostelanos, quienes ellos mismos mostraban reparos a la hora d afirmar que los huesos eran los del Apóstol. 
otros por Acuña Castroviejo (2017), fundamental para entender su proceso de reconstrucción.

Por otro lado tenemos al prelado Payá y Rico, alfonsino declarado y muy próximo a las políticas de León XIII6 y la Unión Católica. Dentro de su estrategia defendió ante el Vaticano la táctica de entendimiento con los gobiernos liberales de la época y se dispuso a luchar abiertamente contra el cabildo, llegando incluso a la suspensión de tres canónigos: Pablo Cuesta, Labín Cabello y por supuesto, López Ferreiro (Barreiro Fernández 1996, 214). Desmontó el carlismo en los centros de poder diocesano e hizo lo posible para que los nombramientos episcopales en Galicia recayesen en hombres de su corte ideológico. Su presencia en Santiago fue crucial para reorientar el potencial ideológico antiliberal por el que se caracterizaba la sede compostelana hacia un nuevo proyecto de reinvención de la tradición jacobea (Villares Paz 2004, 14 y Rey Castelao 2006, 223). Y es precisamente dentro de estos términos de reinvención e inventio - este segundo con un duplo sentido de "encontrar»e «inventar»-,7 donde el prelado se enfrascó en la búsqueda de las reliquias, enmarcada además en de un proyecto de ambición personal que incluía como ulterior objetivo el de ascender a la sede toledana. Hecha su labor, la nunciatura entendió que era el momento de premiar sus servicios haciéndolo Primado en 1886 tras bautizar al propio Alfonso XIII (Barreiro Fernández 1996, 215).

Payá, a diferencia de sus predecesores «ultraconservadores amoldados a la inmovilista dinámica del cabildo compostelano» (Pombo Rodríguez 2001, 170), tuvo el acierto de desempolvar las glorias pasadas y convertirlas en un objetivo a potenciar. Nos vemos inmersos en un contexto de recuperación de cuerpos de santos iniciado con San Francisco de Asís a principios del siglo XIX, y especialmente en el progreso de la historiografía científica en el campo de la historia de la Iglesia, el impulso de la arqueología y el desarrollo científico positivista de la época (Suárez Otero 1999, 47). Con el desarrollo de los estudios de Arqueología Sagrada ${ }^{8}$ - que Villaamil y Castro llegó a calificar como la «ciencia de moda»-, la Iglesia pasó de ver a la ciencia moderna como una enemiga para emplearla en su beneficio, convirtiéndola

\footnotetext{
6 Después de Pío XII, su sucesor León XIII inicia la adhesión de la diplomacia vaticana a los regímenes liberales y consolidados, asumiendo la responsabilidad de alejarse del carlismo y legitimando a Alfonso XIII (Barreiro Fernández 2007, 67).

La «invención de la tradición» es un concepto popularizado por Hobsbawm y Ranger (1983) que propone que muchas de las tradiciones que pueden parecer o que pretendidamente son antiguas, en realidad se han forjado recientemente, a menudo como respuesta a una nueva situación o un tiempo de crisis. La identidad cultural o nacional es adquirida, contingente, tiene un bagaje simbólico y trata de obtener una cierta legitimidad por el hecho de venir desde el pasado. Se puede utilizar para comprender las utilizaciones ideológicas del pasado y los usos políticos de la memoria y la conmemoración, como en el caso que nos ocupa en este artículo.

8 Hay que puntualizar que el término "arqueología» se utilizaba indistintamente para hablar de esta disciplina o de "historia del arte» (Carou Barros 2015, 136). Su importancia capital en los seminarios gallegos es un síntoma clarificador de la importancia que el patrimonio adquirió no sólo en las instituciones civiles, sino también en las eclesiásticas, promocionada desde la propia Roma. La Arqueología Sagrada se entendía en un sentido amplio y decimonónico, donde se daban la mano la historia, la epigrafía, el arte y la diplomática. Esta disciplina se implantó en Santiago en 1887, bajo la breve prelatura de Guisasola Rodríguez (1886-1887) (Requejo Alonso 2005, 153-157).
}

en herramienta legitimadora de sus verdades. En palabras de Requejo Alonso (2005, 143-144 y 155), la ciencia fue «la forma de acercarse a los ambientes más hostiles a la religión al adoptar una metodología moderna de interpretación, pero también en la forma de acercarse a la sociedad dando la apariencia de quien no teme a la ciencia ante la seguridad de sus creencias». La teología descubrió que la ciencia moderna podía «testimoniar, confirmar y demostrar, a través de objetos tangibles, aquellas verdades que ateos y anticatólicos ponían en duda». ${ }^{9}$ La ferviente promoción de esta disciplina desde el papado fue clave para su extraordinario desarrollo. ${ }^{10}$ Queda patente a través de algunos textos de la época, como el publicado en Galicia Diplomática (19-7-1884, 341-343) que asegura: «no sólo sirven hoy las colecciones arqueológicas y los museos de esta clase para esclarecer los problemas históricos, sino que atienden también a ser poderos auxiliares para el arte, proporcionando además utilidad y enseñanza para la industria moderna».

Como indica Villares Paz $(2004,14)$, «el problema no estaba en la ausencia de indicadores externos suficientes para sostener la tradición jacobea, sino en la obtención de una respuesta aparentemente científica a una cuestión que nunca había sido sometida a tal verificación». Además, la historiografía jacobea gozó de un nuevo impulso, ahora motivada ya no por la defensa de los votos y el patronazgo - problemas de los que hablaremos a continuación-, sino más bien por las huellas documentales y arqueológicas que legitimasen esa tradición (Pombo Rodríguez 2001, 167). Por lo tanto, la expedición del prelado buscaba así un certificado arqueológico y un testimonio material de la presencia no sólo del cuerpo sino del sepulcro original del siglo I. Autentificar la existencia del recinto original romano era crucial para la reconstrucción histórica de los hechos. Además, las excavaciones fueron dirigidas por el propio López Ferreiro, figura clave del desarrollo de los estudios de Arqueología Sagrada en Galicia, ya que fue catedrático de esta disciplina en el seminario compostelano desde 1887 hasta 1889, y creador del fundamental manual Arqueología Sagrada (1889). Esta obra fue un hito en la historiografía gallega al aplicar, pese a su cierta subjetividad ya comentada, un cuidadoso rigor científico basado en la comprobación documental y el análisis exhaustivo de las fuentes. Además, la preocupación manifiesta por la conservación y la restauración de los monumentos demuestra su conocimiento de la obra de Viollet-le-Duc (Requejo Alonso 2005, 159-172) y otros teóricos de la arquitectura del mismo corte metodológico como Rafaello Cattaneo en Italia. Esta faceta de su pensamiento y personalidad historiográfica será clave para entender la reconstrucción de la cripta.

Ambas figuras, Payá y Rico y López Ferreiro, se vieron enfrentados ya desde el inicio de las obras. El prelado emprendió un entusiasta plan de remozamiento de la catedral sin consultar al cabildo, que no veía con buenos ojos las

En 1883 se abrieron los Archivos Vaticanos a los investigadores. Además, se promovió la excavación de las catacumbas romanas, apoyando incondicionalmente a los arqueólogos, se creó la cátedra de Paleografía e Historia Comparada, y se abrió el Instituto de Arqueología Cristiana (Requejo Alonso 2005, 143-144).

10 León XIII emitió una circular en 1894 en la que promocionó los estudios fundamentados de Arqueología Sagrada como utensilio de defensa de los dogmas católicos contra los ataques (Villaamil y Castro 1863a, 178). 
reformas y su estilo, lo que comenzó a generar tensiones entre ambas partes, que como decimos, profesaban además ideologías bien distintas (Mera Álvarez 2011, 39-40). La confrontación se acentuó cuando el arzobispo comenzó algo tan determinante como las obras de excavación sin consultarlo con el cabildo. El capítulo, tachando al prelado de imprudente, elevó una serie de recursos a Roma que culminaron en un extenso memorial de quejas que llevó a un ofendido Payá y Rico a publicar en el Boletín Oficial del Arzobispado un Real Decreto del Ministerio de Gracia y Justicia que recordaba de forma poco sutil la incontestable autoridad de los prelados sobre los cabildos; y por otro lado, a la suspensión de licencias al deán José Luis Canosa Ínsua, a Labín Cabello y al propio López Ferreiro (Pombo Rodríguez 2009, 361-366).

Las excavaciones dieron sus frutos al toparse con los restos del edículo apostólico, sin embargo, las reliquias no estaban allí. Realizando las conjeturas pertinentes se llegó a la conclusión de que podrían estar en el trasaltar, lugar que había ocupado la confessio en tiempos de Diego Gelmírez (1100-1140) (Guerra Campos 1982, 111). La noche del veintiocho al veintinueve de enero de 1879 se descubrió en dicho lugar un sepulcro con los restos de tres esqueletos humanos, que se relacionaron con Santiago el Mayor y sus dos discípulos Teodoro y Atanasio, que se sabían enterrados con él a lo largo de la historia de la catedral. Así lo reflejan poco después las actas capitulares:

Habiéndose manifestado el señor deán que [...] se había descubierto en la parte posterior del altar mayor de esta santa iglesia un sepulcro con sagradas reliquias que con toda probabilidad indican ser de nuestro santo patrono el apóstol Santiago, se acordó que los señores comisionados del cabildo se pongan de acuerdo con su eminencia y con él dispongan lo que sea más conveniente a fin de dar a este acontecimiento la mayor publicidad y solemnidad posibles. ${ }^{11}$

Una vez cristalizó el esperadísimo hallazgo, se abrió un impaciente proceso canónico de certificación de la autenticidad de los huesos ${ }^{12}$ que se confirmó definitivamente el 1 de noviembre de 1884 con la bula Deus Omnipotens de León XIII, texto que animaba a los fieles a peregrinar a Santiago. ${ }^{13}$ La ratificación científica por parte de los cate-

11 ACS. Actas capitulares. Libro 79 (IG 634), cabildo del 31-11879, ff. 214r-214v.

12 Las principales fuentes primarias para reconstruir el proceso son las tres cartas pastorales del cardenal Payá (Boletín Oficial del Arzobispado de Santiago 5-2-1879, 49-54; 21-7-1879, 267-276; y 1-81879, 293-312); las hojas del propio Proceso (cuya copia se guarda en el ACS); la bula Deus Omnipotens de León XIII (Boletín Oficial del Arzobispado de Santiago 27-11-1884, 419-432) y las obras de: López Ferreiro (1891 y 1898-1909) y Fita y Fernández-Guerra (1880). También presenta especial interés el artículo de Galicia Diplomática, 237-1882, 17-19.

13 El 12 de marzo de 1883 se remitió el decreto arzobispal a Roma para obtener la confirmación del papa. Monseñor Agustín Caparra, promotor de la Santa Fe, se trasladó a Compostela pasando por Pistoia a identificar el fragmento de cráneo de Santiago que había donado Gelmírez en 1145, mientras el cabildo compostelano comenzaba a impacientarse («... manifestando el señor deán la conveniencia y oportunidad de elevar humildes preces al romano pontífice suplicándole se signe [a] confirmar cuanto antes el decreto de su eminencia Rma. declarando auténticas las reliquias de nuestro Santo Apóstol, sus dos discípulos san Teodoro y san Atanasio, halladas últimamente en la capilla Mayor de nuestra basílica...». ACS. Actas Capitulares. dráticos pertinentes, ${ }^{14}$ dentro del contexto positivista de legitimación arqueológica que ya hemos comentado, fue la gran jugada del bando santiaguista, plasmada en estas palabras del Boletín Arzobispal: "Quedan pues, para siempre, sepultadas las maliciosas dudas que lastimando las seculares tradiciones de un pueblo había suscitado la falsa crítica, despreciadora de tradiciones y aún de probados acontecimientos históricos $» .^{15}$

Como señaló Otero Túñez (1977, 391), «el empuje que el hallazgo dio a la empobrecida ciudad resultó incalculable». No es difícil imaginar lo extraordinario que resultó para una fábrica en decadencia este afortunado episodio, que se tradujo en una intensa revitalización de las peregrinaciones iniciada con el Año Santo especial de 1885. En palabas de Manuel Vidal $(1924,93)$ «la grandeza, solemnidad y entusiasmo con que se celebraron las fiestas patronales de Santiago durante la segunda quincena de julio de 1885 para celebrar tan fausto acontecimiento, forman época en los anales de Compostela». A ello se unió la continua revalorización de la catedral como joya de la arquitectura medieval y el contexto de impulso turístico y ferviente interés por los estilos históricos. ${ }^{16}$ El próspero contexto de revitalización del culto, las peregrinaciones y las artes fue definido por Suárez Otero (2014, 115-116) como «el renacimiento de Compostela».

Las excavaciones sacaron a la luz los restos del edículo que se suponía como el del enterramiento original de Santiago $^{17}$ y tras la confirmación papal comenzaron las obras para acondicionar y dignificar el enterramiento jacobeo: «Manifestó el señor deán la necesidad de hacer alguna obra provisional en la capilla del santo Apóstol, la cual esté en armonía con la custodia y seguridad del santo sepulcro en ella descubierto...». ${ }^{18} \mathrm{El}$ proceso constructivo fue lento, seguramente en parte por la falta de fondos de la fábrica de la que

Libro 80 (IG 635), cabildo del 14-6-1884, sin f.). Tras llevar a cabo las investigaciones, monseñor Caparra regresó a Roma presentando sus resultados a la congregación, quien emitió un decreto de confirmación a la sentencia compostelana el 25 de julio de 1884 . El telegrama de confirmación se lee en la sacristía al día siguiente («Dióse cuenta de la comunicación que a la letra dice así: 'Eminentísimo Señor: Lleno de inefable consuelo y santo júbilo, tengo el honor de remitir a Vuestra Eminencia el adjunto importantísimo documento de la Sagrada Congregación de Ritos, el cual documento contiene el decreto que declara auténticas las reliquias recientemente descubiertas en el ábside de la capilla Mayor de esta santa apostólica y metropolitana iglesia, declaración que ya nos había comunicado el telégrafo, ¡loado sea Dios!'...». ACS. Actas Capitulares. Libro 80 (IG 635), cabildos del 26-7-1884, y 317-1884, sin f.). El primer día de noviembre llegó la solemne ratificación con la mencionada bula.

14 Fueron Antonio Casares, rector de la Universidad de Santiago y catedrático de farmacia, y los doctores Francisco Freire y Timoteo Sánchez, catedráticos de medicina y cirugía. Además, también intervinieron Aureliano Fernández Guerra y Fidel Fita, académicos de la Historia. Véanse Pose Antelo $(1992,41)$ y Suárez Otero $(1999,49)$

15 Boletín Oficial del Arzobispado de Santiago, 7-8-1884, 17.

16 Dentro del revival del arte medieval en el siglo XIX, el ejemplo más paradigmático en Santiago es la valoración alcanzada por el Pórtico de la Gloria desde el célebre texto de Ford (1865), hasta el vaciado que realizó en 1866 el South Kensington Museum de Londres, actual Victoria \& Albert. Sobre este tema, véase Mateo Sevilla (1992).

17 Podemos encontrar una descripción exhaustiva de los restos del edículo hallados en 1878 en Guerra Campos (1982).

18 ACS. Actas Capitulares. Libro 79. 1876-1882 (IG 634), cabildo del 7-2-1879, f. 215v 
a menudo se quejaban los capitulares, ${ }^{19}$ ya que ni Victoriano Guisasola (1886-1888) ni Martín de Herrera (1889-1922) continuaron la labor de mecenazgo del anterior prelado de una forma tan decidida (Mera Álvarez 2003, 155).

\section{TRES PROBLEMAS HISTÓRICOS: PREDICACIÓN, TRASLATIO E INVENTIO DE SANTIAGO}

Lo más interesante del conjunto de la cripta compostelana es la mentalidad con la que está concebida. Todas las elecciones artísticas llevadas a cabo por López Ferreiro están persiguiendo inteligentemente la legitimación del culto jacobeo. Antes de comentar estas opciones estilísticas, repasaremos brevemente la polémica en torno a los tres principales problemas históricos del Apóstol en Hispania, ya que muchos de los argumentos a favor y sus réplicas, fueron afirmados o negados por López Ferreiro empleándolos y traduciéndolos en forma de elementos artísticos.

Entre la lista de fuentes escritas ${ }^{20}$ que fueron forjando la creencia de que el Apóstol estaba enterrado en tierras gallegas encontramos el Breviarium Apostolorum (finales del siglo VI); los textos de Máximo de Zaragoza (ca. 571); el himno atribuido a san Isidoro De ortu et obitu patrum (570-636); los textos de Beda el Venerable y Adhelmo de Malmesbury (segunda mitad del siglo VII), los comentarios de Beato de Liébana (ca. 776-786); el himno visigótico $O$ dei verbum patris (ca. 786); y los martirologios de Floro de Lyon (ca. 808838) y Adón (ca. 860). La tradición nos habla del descubrimiento del sepulcro por el monje eremita Pelayo, quien se lo comunicó inmediatamente a Teodomiro, obispo de Iria. El cuerpo del Apóstol estaría enterrado en un edículo romano del siglo I, que habría cedido para tal propósito una mujer conocida como la reina Lupa a sus dos discípulos, Atanasio y Teodoro, que también se enterrarían con Santiago una vez falleciesen. En el año 834 el rey Alfonso II organizó un viaje al lugar y mandó construir la primera iglesia, a la que comienzan a peregrinar personas venidas de toda Europa.

En el siglo XVI, en parte como fruto del cambio de piedad medieval - más tendente a la leyenda, ritos y tradiciones populares - hacia una espiritualidad más íntima, personal y subjetiva, las peregrinaciones comienzan a decaer (Buide del Real 2017, 307). Asimismo, a partir de la Edad Moderna se abrió un polémico debate en torno a la fundamentación de los principales problemas históricos de Santiago. La aceptación de la cuestión jacobea por parte de las élites política y religiosa españolas no fue homogénea, ni siquiera tras el concilio de Trento (1545-1563), siendo especialmente polémica a partir del siglo XVII. En los debates no solo entraba en juego la dimensión de la fe y las peregrinaciones, sino que esta influía directamente en cuestiones políticas de sumo interés para Compostela como el patronato del apóstol sobre el de Santa Teresa, la primacía de la sede compostelana sobre Toledo, y muy especialmente el Voto de Santiago. ${ }^{21}$ Además entró a debate la aparición de

19 En 1870 se había decretado suspender todas las obras de la iglesia, excepto las más estrictamente necesarias. ACS. Actas Capitulares. Libro 78. 1868-1875 (IG 607), cabildo del 29-3-1870, f. 127v. (1982)

20 Véanse Díaz y Díaz $(1956,1965,1966$ y 1998) y Guerra Campos

21 El Voto de Santiago se traduce en el apoyo económico de la monarquía hispana y las diócesis de su Iglesia a la sede compostelana, la Virgen al apóstol en Zaragoza, ya que los canónigos de la iglesia del Pilar sabían que era imposible explicar tal milagro sin defender antes la predicación santiaguista, por lo que no sólo la sede compostelana estaba interesada en legitimarla. Al igual que Santiago pretendía alzarse en importancia sobre Toledo alegando la presencia de los restos apostólicos, el Pilar zaragozano aspiraba a la condición de primera catedral, por encima de la seo (Serrano Martín 2014, 688).22

Los escritos más críticos con la tradición jacobea de la época pertenecen al arzobispo de Toledo, García de Loaysa (1598-1599), con evidentes intenciones de desacreditar a la fábrica compostelana, así como de los cardenales César Baronio (1538-1607) y Roberto Belarmino (1542-1621). La presencia en el asunto de los italianos se enmarca dentro del proceso del nacimiento moderno de las ciencias eclesiásticas en el periodo postridentino con depuración de leyendas hagiográficas y la revisión de los viejos cronicones medievales alentado por Clemente VIII (1592-1605) (Márquez Villanueva 2004, 315), pero de forma ulterior se enmarca en el contexto de las siempre difíciles diplomacias entre Roma y Madrid. El pontífice mantuvo relaciones bastante tensas con la Corona española, especialmente con Felipe II, con quien estaba enfrentado por el asunto de la Monarquía Sícula o la jurisdicción eclesiástica sobre la isla de Sicilia. Su reforma del breviario de Pío V y la retirada de las referencias de la predicación apostólica en la península ibérica y el enterramiento de su cuerpo en Galicia provocó una reacción de rechazo en Compostela, que buscó ayuda en el monarca. No hay que olvidar que la defensa de la monarquía de la predicación de Santiago se basa también en intereses políticos que legitiman el cristianismo peninsular, así como las victorias cristianas alentadas por el hijo del trueno como la de Clavijo, y la responsabilidad española de defender el cristianismo en América. Baronio y Belarmino arremetieron contra muchas de estas aseveraciones y sin embargo, nunca llegaron a desacreditarlas rotundamente (Serrano Martín 2014, 688-689 y 695). En palabras de Márquez Villanueva (2004, 317-318), «Baronio, Belarmino y en especial Clemente VIII se hallaban cada vez más convencidos del carácter apócrifo de la venida a España de Santiago, pero sabían al mismo tiempo que no podían desafiar a la Majestad Católica». La respuesta hispana a estos textos promocionada por la monarquía fue hilvanada por varias personalidades como Diego del Castillo, el auditor Peña, y especialmente el condestable Juan Fernández de Valladolid (Márquez Villanueva 2004, 319-322).

Durante los siglos XVII y XVIII los novatores, inmersos en la corriente del criticismo histórico, se encargaron de desve-

siendo el apóstol Santiago su patrono, hecho fundamentado tradicionalmente en un pergamino del siglo XII, copia de Pedro Marcio - conservado en el archivo de la catedral-, que reproduce un supuesto original del rey Ramiro tras la batalla de Clavijo en la que se le aparece en sueños el Apóstol dándole ánimos (Buide del Real 2017, 307). El Voto de Santiago y su conflicto histórico ha sido estudiado exhaustivamente por Rey Castelao 1993; 2006, 189-218.

22 La aparición de María a Santiago en Zaragoza también procedía lógicamente de la tradición y estaba fundamentada en fuentes de dudosa legitimación. Jerónimo Román de la Higuera presentó en 1594 los textos apócrifos del Sacromonte como manuscrito de un supuesto Flavio Dextro, que describían este hecho con una excesiva cantidad de detalles. Sobre la falsificación y desacreditación de estas fuentes, véanse Rey Castelao 2006, 16-17 y 75-76, y García-Arenal y Rodríguez Mediano 2019. 
lar los falsos cronicones y elaborar discursos con base documental acerca de la cuestión jacobea. Autores como Nicolás Antonio, el cardenal José Sáenz de Aguirre o el deán de Alicante, Manuel Martí; y muy especialmente el marqués de Mondéjar, Juan de Ferreras y Gregorio Mayans, se mostrarán claramente escépticos, No obstante, ya fuese bien por patriotismo, por piedad religiosa o por temor a la represión y a la Inquisición, y al igual que Baronio y Bellarmino, nunca llegaron a deslegitimar el culto (Serrano Martín 2014, 689 y 696). En palabras de Rey Castelao $(2006,19)$ : «No era posible destruir el mito porque funcionaba como cemento de la unidad de los reinos hispanos".

La historiografía jacobea discutió una y otra vez la autenticidad o fiabilidad de las fuentes medievales, además de otros problemas de raíz histórica y arqueológica. En la época de la segunda inventio la tendencia general se dividió de manera más o menos clara en dos facciones: la línea seguida por López Ferreiro y la línea iniciada por Duchesne. La primera de ellas asumía la autenticidad de los restos apostólicos y por lo tanto, la predicación de Santiago en Hispania y la traslatio tras su martirio en Jerusalén. Defendida especialmente por el fabriquero catedralicio (López Ferreiro 1877; 1883 y 1898-1909), vino seguida por Bartolini (1885); Fita y Fernández-Guerra (1880); Velasco Gómez (1948); Huidobro Serna (1949-1951); Portela Pazos (1953); Ayuso Mazaruela (1954); Elorduy (1954); Torres Rodríguez (1957, 332-351); Carro García (1954 y 1965); y muy especialmente, Guerra Campos (1956, 1971, 1982 y 2003). Tenemos que indicar que los escritos de esta línea argumentativa no se centran en demostrar que las reliquias hoy veneradas en Compostela pertenezcan realmente al apóstol Santiago, sino en demostrar que existen evidencias histórico-científicas que lo hacen posible.

En 1900 veía la luz en Annales du Midi el texto de Duchesne, apoyado por el círculo bolandista y Delehaye. Esta postura afirmaba rotundamente que no existía ningún tipo de evidencia histórica que señalase la predicación de Santiago en Hispania y mucho menos su traslatio, achacando a la historiografía española falta de rigor y credibilidad. Sus principales bazas argumentativas eran el silencio documental hasta el siglo VII -especialmente en autores españoles- y la desconfianza en las fuentes de época medieval que hablan de hechos del siglo I (Díaz Fernández 2004, 28). En España esta línea de pensamiento fue seguida por Pérez de Urbel (1952), Sánchez Albornoz (1971) y Vives (1956).

Las publicaciones más recientes ${ }^{23}$ siguen dándole vueltas a esta polémica cuestión, pero a menudo desde un punto de vista imparcial, preocupado por las evidencias arqueológicas, los distintos asentamientos poblacionales y su relación con las creencias y tradiciones que dieron origen a la inventio, más que por la demostración científica de la predicación y la traslatio, que siguen siendo, por lo menos en cuanto a una afirmación indiscutible se refiere, una cuestión de fe, o en palabras de Kirschbaum «nadie hasta hoy logró dar una explicación satisfactoria del fenómeno compostelano que no fuese del núcleo esencial de la tradición» (cfr. Díaz Fernández 2004, 28).

23 Véanse Temperán Villaverde (2001); Bango Torviso (2003) Mera Álvarez (2003 y 2011); Singul Lorenzo (2004); Taín Guzmán (2006, 2008 y 2010) o López Alsina (2013). Destacan en especial las numerosas publicaciones de Suárez Otero (1999, 2001, 2003 o 2014).

\section{Del PRESENTE al PASAdo: LA INTENCIONADA ELECCIÓN DEL} ESTILO COMO REAFIRMACIÓN DEL CULTO APOSTÓLICO

\subsection{La cripta}

El elemento conceptual más importante del proyecto para un arqueólogo como López Ferreiro fue determinar cómo era exactamente el monumento original del enterramiento, lo cual ha sido siempre una incógnita a despejar. Para ello combinó diferentes fuentes, descripciones y suposiciones con una clara intencionalidad estilística. Las fuentes literarias aluden a un pequeño mausoleo en un «tumulus» (Acta de Consagración de Alfonso III, 889), una "parva arcuata domus» (Carta del pseudo papa León III), ${ }^{24}$ un "arcuatum sepulcrum» (Liber Santi lacobi, ca. 1040) y una "domuncula» o un "mausoleo inferior» (Historia Compostelana, 1107-1140). En cuanto a las fuentes gráficas, el canónigo pudo fijarse en los cuatro ejemplos que habían tratado de representar el túmulo funerario: las miniaturas del Tumbo A de la catedral (1129) y la copia de la Historia Compostelana del Palacio Real de Madrid (ca. 1240) (Fita y Fernández Guerra 1880, 72-73); el grabado de Diego de Astor para la Historia del Apóstol de Castellá Ferrer (1610); y un relieve del retablo del respaldo del camarín en la catedral, anterior a 1640 (Taín Guzmán 2008, 203-204). En todas ellas, el obispo Teodomiro descubre los restos del apóstol en una estancia abovedada, marcándose incluso, en el segundo y cuarto ejemplo, arcos que estructuran la estancia.

El primer elemento material de la reconstrucción fue el edificio funerario tenido por el fabriquero como original, para lo cual se esforzó en analizar los restos arqueológicos, conservarlos y reaprovecharlos en la medida de lo posible, y proponer una reconstrucción basada en todos los modelos de época romana que conocía y que creía contemporáneos y similares al de Santiago. Para ello, puso como ejemplo obras como las tumbas de Absalón y Zacarías en Jerusalén (López Ferreiro 1891, 19-20). El resultado de esta hipótesis constructiva fue un mausoleo tipo domus rectangular, exenta, abovedada y de una sola planta sobre un alto basamento (Fig. 1). ${ }^{25}$ Guerra Campos $(1982,193-194)$ señaló un nutrido grupo de ejemplos de época romana conservados que siguen este tipo, como los sepulcros de Caio Publicio Bíbulo, los cuatro ejemplos de Vía Latina o el templo del dios Redicolo, todos éstos en Roma, o los sepulcros de Fabara, Corbins y La Alberca, en España.

Los restos del supuesto edículo sepulcral romano eran la semilla primigenia de todo el conjunto, los cimientos del culto a Santiago, tanto desde un punto de vista simbólico como arqueológico. López Ferreiro no sólo buscó modelos romanos para reconstruirlo, sino que se preocupó de conservar e integrar los restos aparecidos, manteniendo así los sillares romanos que estaban impregnados de un potente

24 La carta está firmada por un papa León. Tradicionalmente se tomó como un escrito de León III (795-816), contemporáneo al hallazgo y relacionado con Carlomagno. La historiografía ha discutido la fecha y la autoría, barajándose la posibilidad de que sea hasta del siglo XI. Para ampliar sobre esta fuente, véanse David (1951), Guerra Campos (1956) y Díaz y Díaz (1998).

25 Mientras, hipótesis como las de Fita y Fernández-Guerra $(1880,76)$ apuntaban a una edificación de dos pisos, siendo el superior un oratorio y el inferior el lugar de enterramiento, una opción más acertada teniendo en cuenta los datos arqueológicos hallados en las excavaciones y las fuentes escritas. 
componente testimonial, porque no sólo se habían conservado los restos del Apóstol, sino también el receptáculo que sus discípulos habían consagrado a su alma, y más aún, las posibles tumbas de éstos, integradas en los propios paramentos (Suárez Otero 1999, 50) (Fig. 2). Además, en la guía de Santiago de López y López $(1915,60)$, a principios del siglo XX, se alude a la exposición «en vitrinas colocadas al lado de la urna» de materiales originales de la primera construcción hallados en las excavaciones de 1879. Era importante señalar el origen romano del conjunto para demostrar la presencia física anterior a la época visigótica, donde se empezaron a forjar las fuentes escritas y la creencia del enterramiento apostólico. De este modo, la arquitectura se convertía en un agente vivo de la legitimación de las reliquias. Como señaló Suárez Otero (2001, 172-173), la propia estructura del mausoleo actuaba como directa intermediaria entre la relación entre el fiel y el cuerpo santo, y además "el vehículo fundamental de la devoción del creyente».

\section{FIGURA 1}

López Ferreiro: Reconstrucción hipotética del mausoleo apostólico, 1891

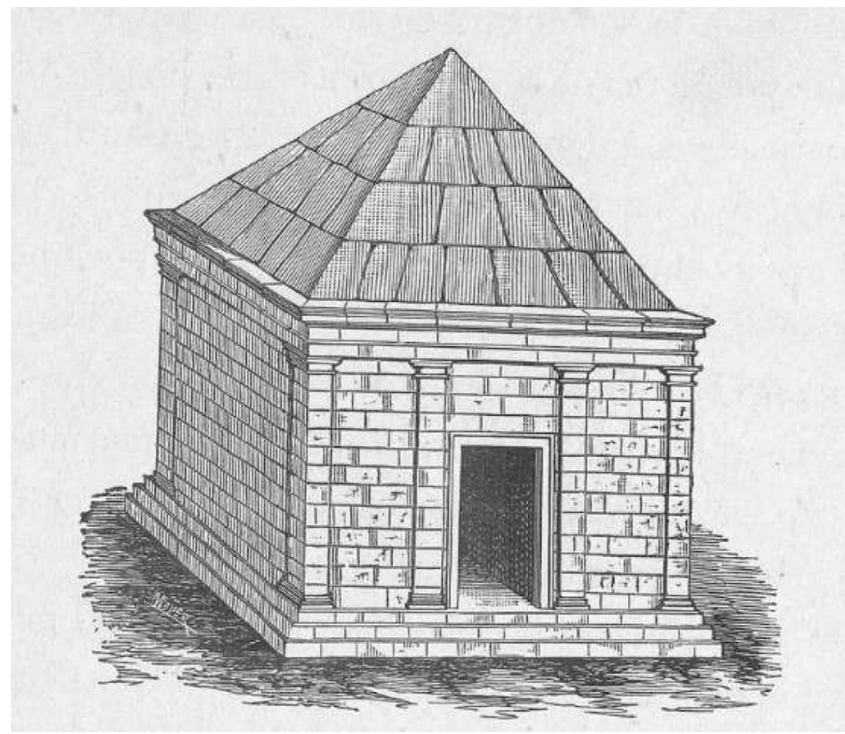

Fuente: Antonio López Ferreiro 1981, 20.

En base a esta primera elección de raíz romana, el segundo elemento fue la idea para reconstruir lo que faltaba. Para ello se basó en la polémica interpretación del término "arca marmarica», mencionado en el Breviarium Apostolorum (siglo VI) como lugar de enterramiento de Santiago. La tradición interpretó la expresión latina como arca de mármol o arcos de mármol, refiriéndose al edificio en sí, línea seguida por algunos investigadores (Torres Rodríguez 1957, 365-369 y López Alsina 2013). Otros estudios señalaron que el término podía referirse a un topónimo -Millán GonzálezPardo $(1990,20)$ apuntó a una desfiguración de «in arcam anmaicam», es decir, "en un castro de la Amaia»; y López $(1935,16)$ relacionó arca con la designación topográfica en relación a un monumento-, o una figura literaria - Marie de Menaca (1995, 209-233) señaló una posible confusión con "arces aethereas», es decir, las alturas del cielo-.

\section{FIGURA 2}

Proyecto de López Ferreiro: Cripta apostólica (lateral), 1884-1886, catedral de Santiago de Compostela

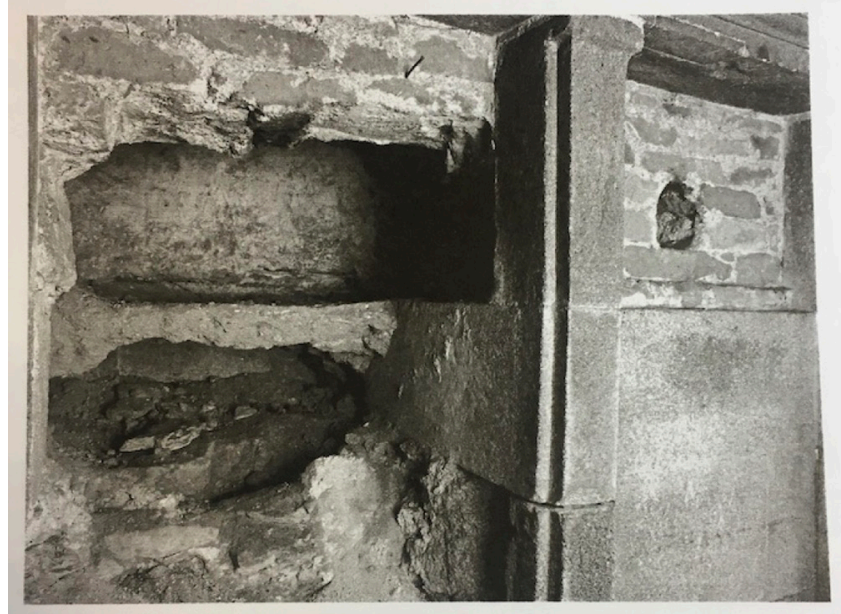

Fuente: Suárez Otero 2001, 171

Lo que nos interesa es que López Ferreiro entendía la expresión en relación a la construcción marmórea del sepulcro original, tal y como estaba representado en las fuentes gráficas que hemos mencionado, y así lo expresa él mismo ${ }^{26}$ haciendo que el arco y el mármol sean los elementos protagonistas de la estancia (Fig. 3). El resultado es una cella organizada por una triple arcada, conservando en la medida de lo posible los muros de sillares originales y cubriendo el resto de ricos mármoles de polícromos, que le otorgan al lugar la poética efectista de una cripta funeraria (Otero Túñez 1977, 392). De este modo, está legitimando las fuentes escritas, rechazadas por los escépticos, tal y como lo habían hecho los artistas que habían plasmado los ejemplos gráficos que hemos comentado anteriormente.

FIGURA 3

Proyecto de López Ferreiro: Cripta apostólica, 1884-1886, catedral de Santiago de Compostela

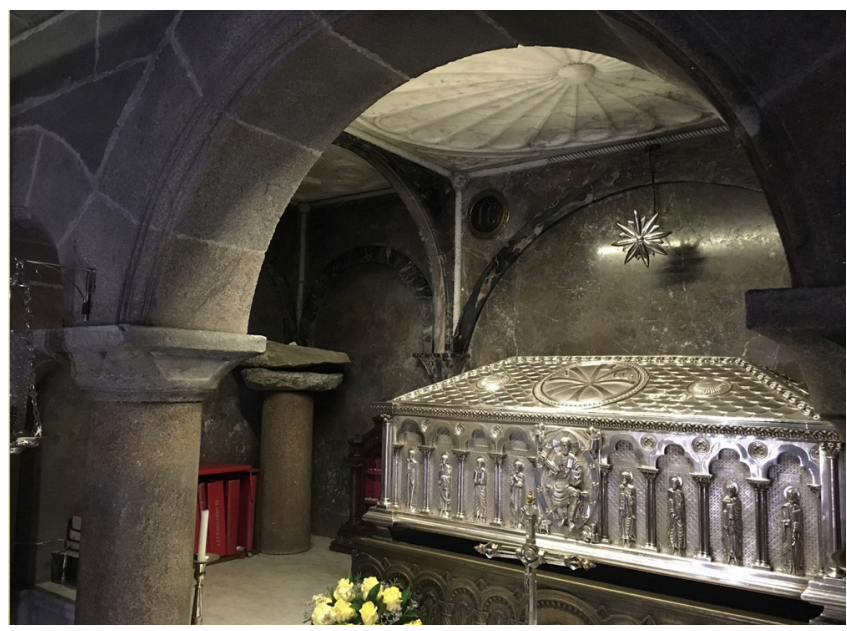

Fuente: fotografía de la autora.

26 Menciona también el término arca, que se refiere a los tipos de construcción sepulcrales conservados en España con los que relaciona la arquitectura original del supuesto edículo (López Ferreiro 1877, 139-142). 
El tercer elemento fue la estructuración arquitectónica de la cella, para la cual el fabriquero dio un salto del siglo I al XII, teniendo muy clara la elección del estilo románico para reafirmar un culto legitimado en la época gelmiriana. De este modo, el estilo escogido para el núcleo catedralicio era el mismo que había revestido la construcción original de la fábrica y que todavía lucía en su estructura y paramentos interiores, a pesar de las reformas barrocas de su epidermis. El románico reflejaba la época en la que la catedral compostelana había sido centro fundamental de la devoción de occidente. Según él mismo, el estilo que denominaba "románico bizantino del tercer periodo» era el idóneo para la reconstrucción porque era el propio de la catedral original, y por lo tanto armonizaba con ella y devolvía a la cripta su estilo de los siglos XI y XII; porque era el más sobrio, severo y reposado de toda la historia del arte; y porque era un estilo que había nacido originalmente en el seno de la Iglesia evolucionado según los ideales cristianos (López Ferreiro 1877, 132). Los elementos decorativos, realizados en mármol de Carrara, siguieron un programa unificado inspirado en modelos románicos de la obra L'Archittetura italiana de Rafaello Cattaneo (1888, 239-257), como indicó el propio López Ferreiro (1891, 144-145). Así, desechaba la envoltura barroca del presbiterio, que no entraba dentro de la mentalidad estética romántica historicista, y daba absoluto protagonismo al arte medieval.

En resumen, López Ferreiro no ideó una cripta moderna, sino que se preocupó de adecuarla lo máximo posible a dos momentos del pasado, o escogiendo dos estilos históricos: el romano y el románico. Estamos ante «el pasado en el presente» de Argan (1977, 7-28), o el entendimiento del pasado a través de la óptica del presente. En este caso, la mentalidad del fabriquero está ligada al pensamiento estético decimonónico del revival medieval, recuperando el estilo románico original de la fábrica. Sin embargo, el fabriquero no está haciendo solamente un uso del historicismo con una vocación artística, sino también histórica. Su intención no sólo es evocar estéticamente el románico, sino sus connotaciones históricas intrínsecas, el pasado glorioso de la catedral.

Debemos tener en cuenta que Diego Gelmírez, primer arzobispo compostelano, empleó todas sus armas disponibles para convertir a Santiago en uno de los epicentros de la Cristiandad occidental. Tras ser nombrado Toledo sede primada en 1088 por el papa Urbano II, la legitimación de la sede compostelana pasaba por la poderosa arma de las reliquias apostólicas. De hecho, muchos obispos de Compostela se habían autodesignado "apostolice sedis episcopus». El traslado de la sede de Iria a Santiago en 1095 y el ascenso a dignidad arzobispal en 1120 fueron la consecución de un proceso en el que Gelmírez había ido usurpando ciertos derechos de la sede de Braga, bastión eclesiástico del occidente peninsular. Para ello el prelado se sirvió continuamente de la presencia del cuerpo de un apóstol tan importante y cercano a Cristo como fue Santiago el Mayor — no debemos olvidar que el papado, de corte reformista, había promocionado el culto a los santos y el ideal de religiosidad de la vida apostólica-, además, intercesor de la monarquía hispana (Herbers 2006, 43-45). La pretensión de Gelmírez no solo era religiosa sino fundamentalmente política, ya que el propio monarca Alfonso VI se había orientado fuertemente hacia la sede toledana. El prelado se ocupó de ganarse los favores de su sucesor, Alfonso VII, siendo su padrino de bautismo e intentando que fuese coronado rey y estableciese su lugar de enterramiento en la basílica compostelana, hechos que finalmente no se materializaron (ibídem, 48-49).

La obra de López Ferreiro a finales del siglo XIX no esconde sino la misma pretensión que la de Gelmírez, la de convertir a las reliquias jacobeas en pulsión latente del sentimiento religioso, justificando así el culto, las peregrinaciones, y la importancia de la catedral de Santiago como uno de los centros clave de la cristiandad occidental que merecía recuperarse tras la penosa situación que había atravesado en el siglo XIX. La pieza cumple así con las palabras de Mera Álvarez $(2011,46)$ :

La vinculación de un estilo arquitectónico con una representación simbólica, bien un sentimiento, como la ya conocida relación entre la arquitectura medieval y la religiosidad y espiritualidad, bien la rememoración de un pasado glorioso, adquiere en estos momentos, y más en la catedral de Santiago, unas especiales connotaciones

\subsection{La urna argéntea}

En cuanto al contenedor propiamente dicho de las reliquias, el osario en el que habían aparecido los restos en 1879 era una tosca solución de emergencia que seguramente se adaptó para ocultar los huesos en 1589 (Guerra Campos 1982, 117-121). Tras certificar su autenticidad, se hizo necesario encargar una urna adecuada para depositar la más preciada pertenencia de la fábrica y colocarla dignamente en su locus más sagrado. Así lo reflejan las actas capitulares pocos días después de la lectura de la bula:

El señor canónigo fabriquero hizo presente que con motivo del decreto de la Santa Congregación de Ritos declarando auténticas las reliquias recientemente descubiertas en el ábside de la capilla Mayor, era necesario hacer una urna de plata para las mismas [...]. El cabildo en su vista acordó que desde luego se tome la plata disponible para hacer la referida urna, autorizando al señor fabriquero para que haga ésta y todas las más obras necesarias que con tal motivo deban practicarse en la cripta, como así mismo para los demás gastos que ocurran en los festejos públicos... ${ }^{27}$

La ejecución del diseño de López Ferreiro se encargó al platero de la catedral, José Losada, ${ }^{28}$ y sabemos que fue ejecutada por sus dos oficiales Ricardo Martínez Costoya ${ }^{29}$ y Eduardo Rey (Fig. 4). Éstos terminaron la obra que su maestro no pudo ver finalizada, ya que murió en 1887. Los modelos escultóricos fueron vaciados por Ángel Bar y Manuel Corgo (Galicia Diplomática, 22-7-1888, 217).

\footnotetext{
27 ACS. Actas Capitulares. Libro 80. (IG 635), cabildo del 2-81884 , sin $\mathrm{f}$.

${ }_{28}$ José Losada fue el platero más importante del tercer cuarto del siglo XIX en Compostela. Su primer trabajo para la fábrica y el más célebre junto a la urna, es el actual botafumeiro. Fue artífice oficial de la fábrica entre 1853 y 1886 . Murió en el sanatorio de Conxo en 1887. Sobre este artista, véase Pérez Varela (2018).

29 Sobre este artista y en concreto sobre la urna de los restos del Apóstol, véase Pérez Varela (2019).
} 


\section{FIGURA 4}

Ricardo Martínez y Eduardo Rey: Urna apostólica, 18841891, catedral de Santiago de Compostela

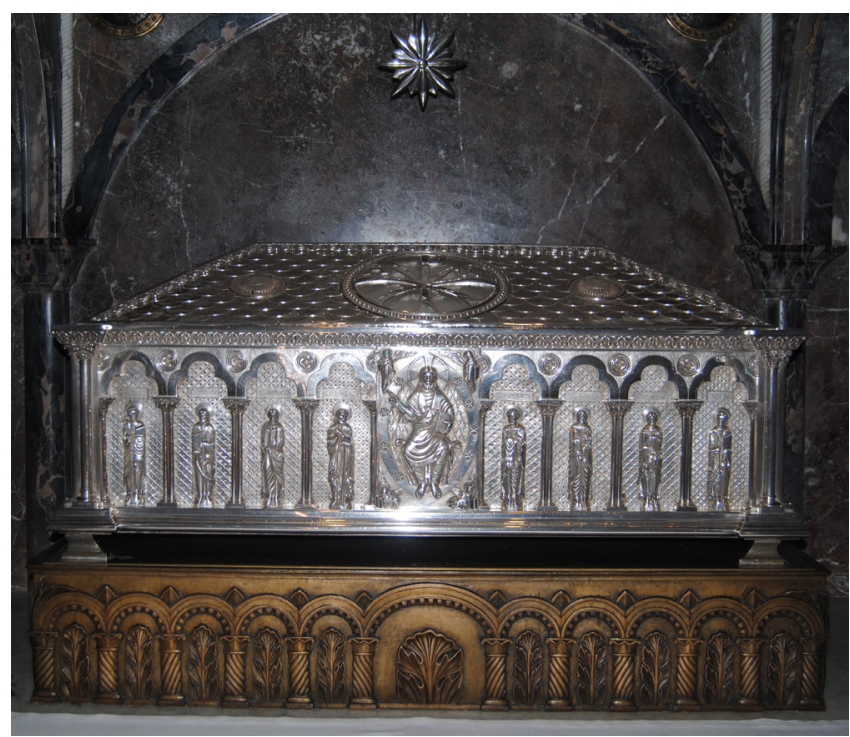

Fuente: fotografía de la autora.

La obra tiene un claro referente de inspiración, que tiene que ver con un momento clave de la catedral compostelana como es la remodelación del presbiterio llevada a cabo por el arzobispo Gelmírez (1100-1140). Hacia 1137, el prelado colocó tras el altar mayor su célebre tabula retro altaris ${ }^{30}$ (López Ferreiro 1898-1901, IV: 157-158) un retablo de plata de tipo políptico, que Fernández Sánchez y Freire Barreiro $(1880,44)$ describieron como «una de las más interesantes [obras] de la orfebrería de la Edad Media». Esta pieza contaba con una forma pentagonal a modo de frontón, y estaba decorada en relieve con el Salvador, los doce Apóstoles y la
Virgen, organizados en arcos trilobulados entrepilastrados (Moralejo Álvarez 1980; Taín Guzmán 2008 y 2010 e Yzquierdo Peiró 2017, 255).

Perdida en la reforma barroca del presbiterio, la conocemos gracias a un dibujo del célebre Informe (1657) del fabriquero José Vega y Verdugo (1623-1696) (Sánchez Cantón 1956, 7-52), interesantísimo documento que motivó dicha reforma en el siglo XVII (Taín Guzmán 2008), y que nos da dos versiones de la obra. La primera es la original ya descrita. La segunda es la del aspecto que tendría en tiempos del propio Vega y Verdugo, con las modificaciones realizadas en 1560 por el platero vallisoletano Juan Álvarez (Taín Guzmán 2008, 208-210) (Fig. 5). Éste encajó la plancha en una estructura rectangular de madera con friso decorado y ceñida en sus vértices por columnas de orden gigante, modificaciones que hicieron que la obra gelmiriana perdiese su naturaleza tipológica de retablo y pasase a ser un arca. Así se encontraba cuando la describió Ambrosio de Morales en 1572 (Flórez 1765, 120). ${ }^{31}$ De hecho, en el Informe, el fabriquero señaló el remate como una «tapa la qual la dexaron en pie los plateros, porque si se escorçaran no se biera ni goçara la plata» (Sánchez Cantón 1956, 34). Por lo tanto, Vega y Verdugo entendía la forma pentagonal desglosada en un frontal y una cubierta, aplanada ésta para poder ser vista de frente.

Precisamente, esta tipología de arca y distribución morfológica - caja rectangular, columnas de orden gigante, friso decorado, cubierta triangular - fue la que adoptó López Ferreiro para el diseño de la urna actual. La obra está decorada al frente y ambos lados por una sucesión de dieciocho arcos trilobulados con dobles columnas de fuste liso y capiteles vegetales, y está techada por una cubierta a cuatro aguas ornamentada con un campo de escamas de pez. Las horna-

\section{FIGURA 5}

Obrador compostelano: Tabula retro altaris, ca. 1137 y ca. 1560, catedral de Santiago de Compostela
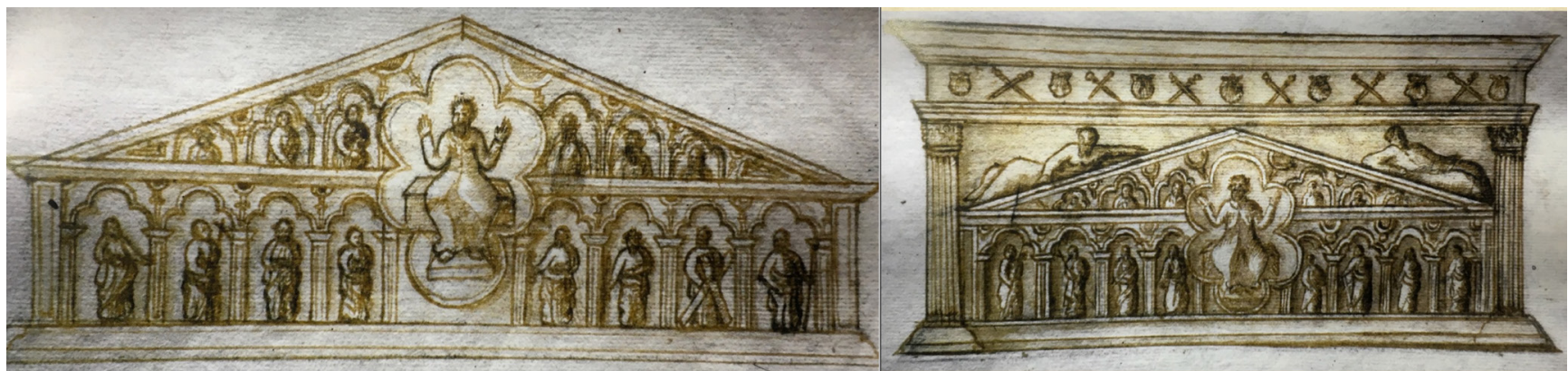

Fuente: Sánchez Cantón 1956, 33 y 35.

30 Con anterioridad, se había colocado en 1105 un altar que Ambrosio de Morales describió decorado con figuras de medio relieve representando al Pantocrátor entronizado, los cuatro evangelistas sosteniéndolo, los veinticuatro señores del Apocalipsis rodeándolo y los doce apóstoles entrecolumnados a los lados (Flórez 1765, 119). Presentaba una inscripción en latín que Zepedano tradujo como: «Hizo la obra el obispo compostelano Diego Il en el quinto año de su pontificado y tiempo del rey Alfonso y de su yerno el conde don Ramón, siendo el coste setenta y cinco marcos de plata, pagados del tesoro de la iglesia» (Zepedano y Carnero 1870, 89-90). Lógicamente presentaría una filiación estilística importante con la tabula retro altaris. cinas acogen dieciocho figuras con cartela identificativa grabada con letra de estilo medieval, entre las que encontramos al Salvador central en mandorla, la Virgen con el Niño,

\footnotetext{
31 La transformación del retablo en arca provocó confusiones entre algunos peregrinos, quienes pensaron que el cuerpo descansaba físicamente dentro del mismo altar. Se conservan testimonios que así lo señalan, como el obispo armenio Mártir de Arzendjan (1429); Corsini y Lorenzo Magalotti sobre el viaje de Cosme III de Medici (1669) o Domenico Laffi (1673) (Guerra Campos 1982, 104-105).
} 
algunos de los apóstoles y por supuesto, Santiago el Mayor y una serie de personajes relacionados con el culto jacobeo. ${ }^{32}$

La serena simplicidad, los pliegues ondulantes y variados, los detalles de cenefas y dibujos de las ropas, la expresión hierática, la frontalidad y el código de posturas y miradas que sugiere una tímida interacción, nos remite a modelos formales hallados en la maravillosa enciclopedia visual de obras maestras como es la propia catedral, que López Ferreiro tenía cada día a su vista. Entre ellos podemos contar la portada de Platerías - el Cristo gótico del friso del frontispicio de la portada está reflejado en la figura que centra el lateral izquierdo-, o el coro y el Pórtico de la Gloria del maestro Mateo. El Pantocrátor deriva como señaló Otero Túñez $(1977,393)$, de aquel proveniente de la crestería de la fachada del Tesoro, figura custodiada hoy en el museo catedralicio.

La repisa broncínea, realizada íntegramente por Ricardo Martínez, fue construida con el material resultante de fundir íntegramente la lápida funeraria del arzobispo Sanclemente, el mismo que había escondido las reliquias en 1589. A pesar de que ésta pudo ser una decisión que tuvo más que ver con la necesidad de disponer de material que con su filosofía artística, el propio López Ferreiro intentó justificarlo de forma simbólica. Dejó por escrito que se trataba de una decisión consciente para poetizar así el suceso de la pérdida y el hallazgo de las reliquias, cerrando el capítulo con el mismo que lo inició; y contando además que, durante el descubrimiento del osario, se tapó el agujero del pavimento con dicha lápida broncínea para protegerlo (López Ferreiro 1891, 32).

Lo que nos interesa es que la urna resulta también una declaración de intenciones al conjugar los dos mismos estilos históricos: romano y románico. El primer elemento o lo romano, resulta de la transformación del retablo gelmiriano en un arca, hecho que como hemos mencionado, ya había sucedido en el siglo XVI al encajar ésta en una estructura lígnea. En el caso de López Ferreiro, éste configuró la urna con una cubierta a cuatro aguas, consiguiendo el tipo de enterramiento que él entendía por romano y que debió de parecerle el más adecuado para el enterramiento del apóstol, aunque ahora sepamos que estilísticamente no se corresponde con el siglo I.

El segundo elemento o lo románico, es la adaptación de la tabula retro altaris de Gelmírez, evocando así la obra que tanto había llorado la historiografía del siglo XIX..$^{33} \mathrm{Su}$ aspecto románico, basado en parte en la inspiración mateana, es indiscutible, y fue elogiado en la propia prensa de la época como una obra que no sólo presentaba una brillante calidad artística sino una veracidad historicista que podría engañar a un ojo experto (Galicia Diplomática, 22 de julio de 1888, 217).

32 A la derecha del Salvador encontramos a Santiago el Mayor, san Juan, san Mateo y san Teodoro. A su izquierda, san Pedro, san Andrés, san Pablo y san Atanasio. La parte lateral izquierda está presidida de nuevo por Cristo, san Pedro, santo Tomás, un segundo Santiago el Mayor, y san Bartolomé. Centrando el lateral derecho tenemos a la Virgen María con el Niño, María Salomé - madre de Santiago-, san Juan, san Simón Tadeo, Santiago el Menor, y san Torcuato, varón apostólico.

33 Sentenach $(1909,64)$ se lamentó a principios del siglo XX de su sustitución por el baldaquino barroco con estas palabras: «digno de uno que le hubiera impedido cometer profanación tan incomprensible, pero a tanto ha llegado en ciertos momentos el imperio de la moda».
Gracias a la fusión de un sarcófago con el retablo, volvemos a tener un diálogo romano-románico en la urna, o siglo I-siglo XII, como sucede en la arquitectura que envuelve la obra. Podemos hallar la misma idea en otras obras artísticas encargadas por la catedral en este contexto de legitimación de la segunda inventio. El ejemplo más significativo lo constituye el tríptico Las Tradiciones del Apóstol Santiago en Galicia (ca. 1897) de Modesto Brocos (Yzquierdo Peiró 2017, 249-250) (Fig. 6), pintura muy significativa con respecto al contexto de reafirmación de la autenticidad de las reliquias, porque ilustra y materializa los tres problemas del debate histórico: predicación, traslatio e inventio. La inventio está ilustrada en la parte central, y la urna aparece custodiada por ángeles y bañada por la luz de la estrella, presentándosenos como un sarcófago paleocristiano a todos los efectos, con un frente de estrígiles, hecho que ya señaló como curioso Otero Túñez (1977, 393-394). Seguramente el pintor pudo ver ejemplos al respecto en su estancia en Roma. El hecho de que la cubierta sea prácticamente idéntica a la urna actual nos hace pensar que Brocos se inspiró en la obra de Martínez y Rey. La filiación paleocristiana de la urna quedaría todavía más subrayada con esta referencia arqueológica de Brocos que demuestra una intención de ambientar la escena sagrada de la forma más naturalista y veraz posible, entendiendo el paleocristiano de forma anacrónica como una referencia válida para el siglo I.

\section{FIGURA 6}

Modesto Brocos: Las Tradiciones del Apóstol Santiago en Galicia (ca. 1897), catedral de Santiago de Compostela

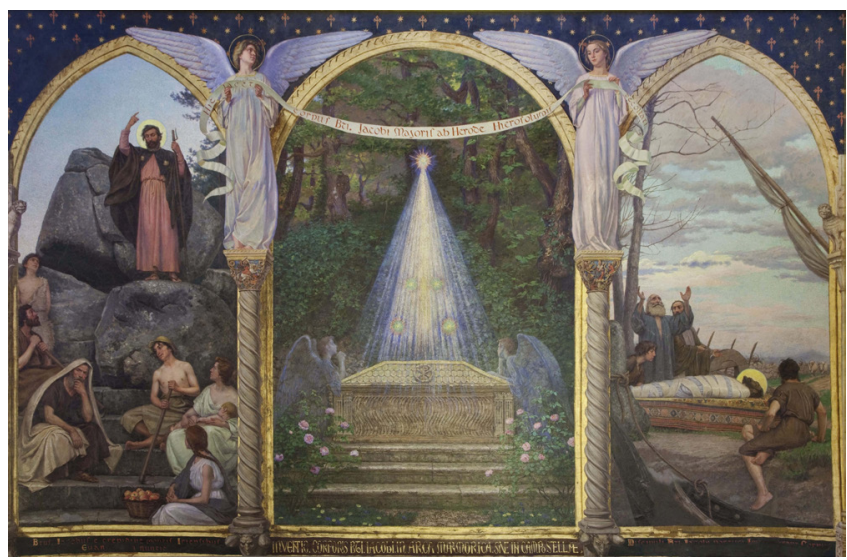

Fuente: imagen cedida por Fundación Catedral de Santiago @C.

Queda todavía un tercer elemento, ciertamente interesante, y es que la iconografía escogida para la urna también es fruto de la política legitimadora del fabriquero, al colocar a cuatro personajes que no aparecían en el retablo de Gelmírez, pero que están relacionados con el culto jacobeo. Entre ellos sorprende especialmente la presencia de María Salomé. Según Gómez Darriba (en prensa), ${ }^{34}$ la promoción

34 En el XI Congreso de la Sociedad Española de Emblemática (Santiago de Compostela, 2017) Gómez Darriba presentó una comunicación al respecto de la figura de María Salomé, cuyas actas están próximas a publicarse, y que constituirá una referencia obligada para analizar la iconografía de la santa y su configuración en la Compostela medieval en relación al interés de la iglesia gelmiriana por rendirle culto. Agradecemos al autor su amabilidad por la consulta de su manuscrito. 
del culto a la madre de Santiago podría ser inédito de Compostela teniendo origen en el siglo XII, en el contexto en el que el arzobispo Gelmírez trataba de legitimar las reliquias jacobeas y posicionar a la sede compostelana como una de las más importantes de la cristiandad. Una vez más, López Ferreiro está apoyándose en las ideas que Gelmírez tuvo en la construcción de la catedral medieval para perseguir el mismo objetivo: la legitimación del culto y la contextualización de Santiago el Mayor rodeándolo de los personajes que la literatura exegética y la tradición le atribuían, y que la historiografía crítica de la Edad Moderna tildaban de invenciones medievales sin fundamento histórico.

La misma intención subyace al añadir a sus discípulos Atanasio y Teodoro, y al varón apostólico Torcuato. Según Castellá Ferrer, y citando al obispo Sampiro de Astorga, estos discípulos fueron Calocero, Basilio, Pío, Crisógono, Teodoro, Atanasio y Máximo. El escritor señaló a Teodoro y Atanasio como los dos que recibieron sepultura con él, citando la polémica Espistola Leonis (Castellá Ferrer 1610, 134r y 142v). Recogiendo esta información, López Ferreiro citó asimismo el Códice Calixtino, donde se aludía a Atanasio, Teodoro, Torcuato, Segundo, Indalecio, Tesifonte, Eufrasio, Cecilio y Hesiquio (López Ferreiro 1877, 11-12). Los siete últimos se han identificado tradicionalmente como los "Varones Apostólicos ${ }^{35}$, de los que existen a su vez varias concepciones. La primera es la empleada por López Ferreiro, donde se habla de los Varones como acompañantes de Santiago en su evangelización de Hispania - a diferencia de los «discípulos», que acompañaron su cuerpo de Jerusalén a Galicia tras su muerte- - La segunda, más aceptada, y extendida por el padre Flórez, es la que considera que estos personajes habrían sido mandados por san Pedro y san Pablo y habrían evangelizado el sur de España. Según la línea historiográfica detractora de la autenticidad de las reliquias, opuestos a considerar la presencia de Santiago en Hispania, la tradición jacobea habría "plagiado» estas figuras para apoyar su causa (Guerra Campos y Cebrián Franco 2003, 499, nota 82). Esta misma línea historiográfica rechaza también la traslatio y por consiguiente la existencia de los discípulos, tildándolos de una «invención medieval». ${ }^{36}$

\subsection{El altar}

Aunque siempre hemos hablado de reconstrucción de la cripta, el repaso a este conjunto artístico no estaría completo sin una breve mención a la mesa del altar mayor, parte del plan orquestado por López Ferreiro. Al igual que el trabajo marmóreo del subsuelo, el altar también fue ejecutado por el taller de Ramón Constenla, ${ }^{37}$ está en la misma línea estilística definida por el término "románico bizantino del tercer periodo» que el propio fabriquero empleó para unifi-

35 Para ampliar sobre los Varones Apostólicos, véase García de Villada 1928, 151.

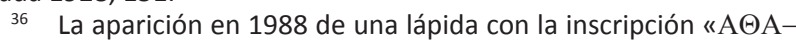
$\mathrm{NA} \Sigma \mathrm{IO} \Sigma »$ en las excavaciones arqueológicas del mausoleo del Apóstol significó una baza muy importante para el bando defensor en la lucha historiográfica sobre la cuestión jacobea. Sobre este descubrimiento véase Millán González-Pardo 1990.

37 Los mármoles procedían del establecimiento coruñés de Baltasar Escudero, así como de Aspe y Alicante, de donde llegaron en barco. ACS. Facturas, recibos, cuentas varias, 1879-1885 (IG 1027), carpetilla de «1885. Cripta», sin $\mathrm{f}$. car el conjunto bajo los criterios anteriormente expuestos, y poetizado por él mismo de este modo «el estilo románicobizantino es en la arquitectura, lo que el género diatónico es en la música. Así como este género por lo grave, mesurado, lo solemne de sus melodías es el más a propósito para el templo, así el estilo románico-bizantino por lo sobrio...» (López Ferreiro 1891, 12).

La mesa (Fig. 7), de tres metros de largo, está construida en mármol blanco de Carrara veteado de gris, y ornamentada con una sucesión de arcadas de medio punto que apoyan en pilastras, abrazando cada uno de ellos una arcada menor, compuesta por tres arcos en cada caso, que reposan en elegantes semicolumnas de capiteles corintios con sobrio fuste liso. Tenemos por lo tanto una cohesión estilística románica con la obra principal del subsuelo, a la cual está coronando, y de nuevo subyace en este elemento el termino "arcos de mármol» como leitmotiv que funciona de hilo conductor.

\section{FIGURA 7}

Obrador de Ramón Constenla: Altar, 1891, catedral de Santiago de Compostela

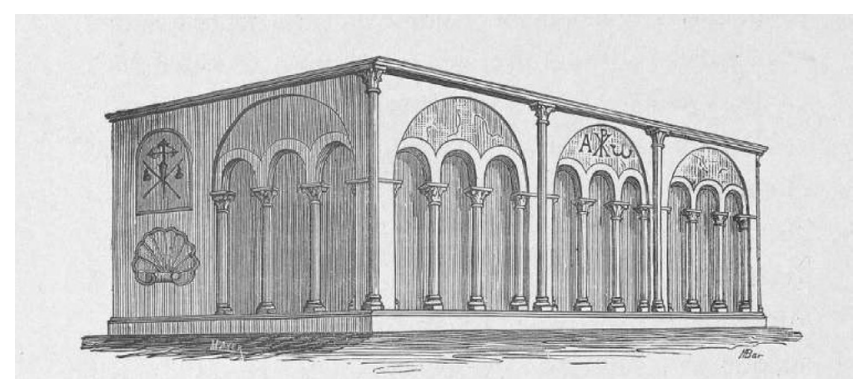

Fuente: López Ferreiro 1891, 13.

López Ferreiro mantiene así la organización del presbiterio orquestada en el siglo XII por Gelmírez, compuesta por una sucesión ascensional de: cripta-altar-baldaquino (Taín Guzmán 2008, 211), devolviendo el estilo románico a los dos primeros elementos, y manteniendo irremediablemente la enorme estructura barroca de Vega y Verdugo que abraza la capilla mayor. Teniendo en cuenta que en la época gelmiriana la cripta estaba cerrada al tránsito, todo el esplendor se concentraba en la riqueza argéntea sobre el suelo del presbiterio. En el caso de López Ferreiro, con la apertura de la cripta original, se gana no sólo un lugar de culto y veneración propio del fenómeno de las peregrinaciones, sino también una evidencia arqueológica, y se devuelve al edículo romano toda su importancia testimonial y simbólica.

\section{CONCLUSIÓN}

Queda claro que la iglesia compostelana supo emplear el poder de la arquitectura y las artes plásticas para celebrar el hallazgo que la volvía a situar como uno de los epicentros del culto cristiano, siguiendo así López Ferreiro la intención que demostraron con anterioridad el arzobispo Diego Gelmírez y el fabriquero Vega y Verdugo. El primero nos retrotrae a la época áurea de la fábrica jacobea y a las aspiraciones del prelado a legitimarse por encima de Toledo empleando el poder de las reliquias, y el segundo nos lleva 
hasta el siglo XVII, con las reformas barrocas del presbiterio para la cuales el fabriquero se sirvió de modelos romanos que dotasen al cenotafio de la dignificación gloriosa que merecía. En el siglo XIX, López Ferreiro y la iglesia compostelana recogieron esas aspiraciones y pretendieron cerrar siglos de crítica historiográfica detractora de la autenticidad de las reliquias. Además, debemos insertar este hecho en un contexto político de lucha entre el liberalismo y el carlismo, donde las cuestiones relativas al Voto de Santiago fueron duramente atacadas, así como un contexto religioso en el que Santiago necesitaba reafirmarse como centro de peregrinación y recuperar el esplendor pasado.

López Ferreiro confeccionó su estrategia promocional a través del arte en dos sentidos: por un lado, la remodelación de una cripta y un sepulcro de plata que empleó el estilo histórico como reafirmación de su pasado glorioso, para entroncarlo directamente con un presente y futuro igual de fructífero. Por otro, a través de obras plásticas de carácter decorativo -entre ellos, el mencionado tríptico de Brocos- cuyo contenido ilustraba directamente las creencias que habían sido duramente atacadas por la historiografía criticista, creando de este modo un imaginario iconográfico que defendía y certificaba la presencia de Santiago en Hispania.

No cabe duda de que estamos ante una obra excepcional y un lugar sin comparación. Según López Ferreiro y la estrategia historicista de finales del siglo XIX, el locus más sagrado de la basílica jacobea no conserva solamente los supuestos restos del Apóstol, sino que posee un simbolismo territorial intrínseco. Es ese pequeño espacio de tierra el que según la tradición tuvo contacto directo con los discípulos de Santiago, que trajeron su cuerpo desde Jerusalén y escogieron ese lugar para enterrarlo. Los restos arqueológicos del edículo sepulcral del siglo I actúan, en palabras de López Ferreiro $(1891,34)$, como auténticos «cimientos históricos de nuestra fe». Sobre éstos, se genera un diálogo con el arte románico, propio de la época de Gelmírez, devolviendo así a la fábrica el estilo medieval de su concepción primigenia y emulando su esplendor como centro clave de la cristiandad occidental en el siglo XII.

Este diálogo historicista de los siglos I-XII transporta la catedral decimonónica a sus dos momentos históricos claves vertebrando su discurso a través de los términos, elementos y personajes de la literatura exegética e histórica - fuentes arqueológicas, escritas, gráficas e iconográficas- que constituían los principales argumentos de la afirmación de la autenticidad de las reliquias. De este modo, este singular epicentro irradiador de un culto, de una cultura de peregrinación y de un fenómeno único, se creó a través de una filosofía basada en el uso del historicismo como evocador de las características históricas de dos épocas concretas, empleando los elementos artísticos como legitimadores y evocadores de sus fundamentos religiosos, persiguiendo a su vez, de forma velada pero evidente, una pretensión de primacía política de la sede compostelana.

\section{FUENTES}

Borrow, George. 1996. La Biblia en España. Madrid: Alianza Editorial. Castellá Ferrer, Mauro. 1610. Historia del Apóstol de lesus Christo Sanctiago Zebedeo Patrón y Capitán General de las Españas. Madrid: Alonso Martínez de Balboa.
Cattaneo, Rafaello. 1888. L'archittetura in Italia. Venecia: Tipografía Emiliana.

Duchesne, Louis. 1900. «Saint Jacques en Galice». Annales du Midi 12: 145-179.

Fernández Sánchez, José María; y Francisco Freire Barreiro. 1880. Santiago, Jerusalén, Roma: diario de una peregrinación a estos y otros santos lugares de España, Francia, Egipto, Palestina Siria e Italia en el año del jubileo universal de 1875. Santiago de Compostela: Imprenta del Boletín Eclesiástico.

Fita, Fidel, y Aureliano Fernández-Guerra. 1880. Recuerdos de un viaje a Santiago de Galicia. Madrid: Imprenta de los Sres. Lezcano y Compañía.

Flórez, Enrique. 1765. España Sagrada, tomo XIX: Contiene el estado antiguo de la iglesia iriense y compostelana hasta su primer arzobispo. Madrid: Antonio Martín.

Ford, Richard. 1845. A handbook for Travellers in Spain and Readers at Home. Londres: John Murray.

López Ferreiro, Antonio. 1877. El altar de Santiago, sus vicisitudes y transformaciones desde los tiempos primitivos hasta nuestros días. Santiago de Compostela: Imprenta del Boletín Eclesiástico.

López Ferreiro, Antonio. 1883. Las tradiciones populares acerca del sepulcro del Apóstol Santiago. Santiago de Compostela: Imprenta de la Gaceta.

López Ferreiro, Antonio. 1891. Altar y cripta del apóstol Santiago. Reseña histórica desde su origen hasta nuestros días. Santiago de Compostela: Imprenta y Encuadernación del Seminario Conciliar Central.

López Ferreiro, Antonio. 1898-1909. Historia de la Santa Apostólica Metropolitana Iglesia de Santiago de Compostela, 11 vols. Santiago de Compostela: Seminario Conciliar Central.

Villaamil y Castro, José. 1863a. "Arqueología Sagrada (I)». El Museo Universal VII, 23: 178-179.

Villaamil y Castro, José. 1863b. "Arqueología Sagrada (II)». El Museo Universal VII, 24: 186-187.

Villaamil y Castro, José. 1866. Descripción histórico-artística-arqueológica de la catedral de Santiago. Lugo: Imprenta de Soto Freire.

Zepedano y Carnero, José María. 1870. Historia y descripción arqueológica de la Basílica Compostelana. Lugo: Imprenta de Soto Freire.

\section{BiBLIOGRAFÍA}

Acuña Castroviejo, Fernando. 2017. «López Ferreiro, arqueólogo, y las excavaciones en la Catedral de Santiago dentro del contexto europeo de la época: una visión en el siglo XXI» en La renovación de las peregrinaciones a Santiago de Compostela en el siglo XIX: entre tradición y modernidad, edición de Antón Pazos, 47-61. Santiago de Compostela: Instituto de Estudos Galegos Padre Sarmiento.

Argan, Giulio Carlo. 1977. El Pasado en el Presente: el revival en las artes plásticas, la arquitectura, el cine y el teatro. Barcelona: Gustavo Gilí.

Ayuso Mazaruela, Teófilo. 1954. "Standum est pro traditione». En Santiago en la historia, la literatura y el arte, coordinación de Francisco Íñiguez Almech, 83-126. Madrid: Editora Nacional.

Bango Torviso, Isidro Gonzalo. 2003. «El 'Locus Sanctus' de Santiago de Compostela: una nueva interpretación del escenario arquitectónico del santuario». En Congrés Internacional 'El camí de Sant Jaume', 191-220. Barcelona: Cervera i Lleida.

Barreiro Fernández, Xosé. 1978. «López Ferreiro e a recuperación histórica de Galicia». Encrucillada 8: 213-226.

Barreiro Fernández, Xosé. 1996. «Edad Contemporánea: los hombres del altar (Aproximación al clero como grupo social)». Sémata 7-8: 181-234.

Barreiro Fernández, Xosé. 2007. A Gran Historia de Galicia: Historia política da Galicia Contemporánea. A Coruña: La Voz de Galicia.

Bartolini, Domenico. 1885. Apuntes biográficos de Santiago Apóstol el Mayor y exposición histórico-crítica y jurídica de su apostolado, traslación del cuerpo del mismo a España y su reciente descubrimiento. Roma: Tipografía Vaticana.

Buide del Real, Francisco Javier. 2017. «Removiendo Roma con Santiago: la crítica católica moderna al culto jacobeo». Compostellanum 62: 305-356. 
Carou Barros, Pablo. 2015. Recepción de la edad media en la historiografía del arte gallego: José Villaamil y Castro, 1838-1910. Tesis doctoral. Universidade de Santiago de Compostela.

Carro García, José. 1954. Estudios jacobeos: ara marmórica, cripta, oratorio o confesión, sepulcro y cuerpo del Apóstol. Santiago de Compostela: Instituto de Estudos Galegos Padre Sarmiento.

Carro García, José. 1965. A pelengrinaxe ao Xacobe de Galicia. Vigo: Galaxia.

David, Pierre. 1951. «Notes Compostellanes. La lettre du pseudo-León sur la translation de Saint Jacques». Bulletin des Études Portugaises et de l'Institute Français au Portugal 15: 180-193.

Díaz Fernández, Xosé María. 2004. «O sartego de Santiago. Entre a relixiosidade popular e a ciencia histórica». Grial 161: 28-33.

Díaz y Díaz, Manuel Cecilio. 1956. "El lugar de enterramiento de Santiago el Mayor en Isidoro de Sevilla». Compostellanum I, 4: 365369.

Díaz y Díaz, Manuel Cecilio. 1965. "La literatura jacobea anterior al códice calixtino». Compostellanum X, 4: 283-305.

Díaz y Díaz, Manuel Cecilio. 1966. «Estudios sobre la antigua literatura relacionada con Santiago el Mayor». Compostellanum XI, 4: 621666.

Díaz y Díaz, Manuel Cecilio. 1998. «La Epistola Leonis Pape de Translatione Sacti lacobi in Gallaeciam». Compostellanum 43 (1-4): 517 568.

Duchesne, Louis. 1900. «Saint Jacques en Galice». Annales du Midi 12: 145-179.

Elorduy, Eleuterio. 1954. "De re jacobea». Boletín de la Real Academia de la Historia 135: 323-335.

García-Arenal, Mercedes y Fernando Rodríguez Mediano. 2019. "Las falsificaciones del Sacromonte de Granada y la erudición de los siglos XVII y XVIII: la creación de una historiografía crítica». En Memoria de los orígenes: el discurso histórico-eclesiástico en el mundo moderno, coordinación de José Jaime García Bernal y Clara Bejarano Pellicer, 529-547, Sevilla: Universidad de Sevilla.

García Iglesias, José Manuel. 2013. Secretos de Catedral: la basílica de Santiago de Compostela a través de sus tiempos y espacios. Santiago de Compostela: Consorcio de Santiago - Alvarellos.

García de Villada, Zacarías. 1928. Historia eclesiástica de España. Madrid: Compañía Ibero-Americana de Publicaciones.

Gómez Darriba, Javier. En prensa. «Santa María Salomé. Culto e iconografía de la madre del apóstol Santiago en la ciudad de Compostela». En Comunicación en el XI Congreso de la Sociedad Española de Emblemática, 2017.

Guerra Campos, José. 1956. «La carta del papa León sobre la traslación de Santiago en el manuscrito 1104 de la Biblioteca Casanatense». Compostellanum 1: 129-140.

Guerra Campos, José. 1971. «Bibliografía (1950-1969). Veinte años de estudios jacobeos». Compostellanum XVI: 575-712.

Guerra Campos, José. 1982. Exploraciones arqueológicas en torno al sepulcro del Apóstol Santiago. Santiago de Compostela: Cabildo de la Catedral de Santiago de Compostela.

Guerra Campos, José. 2003. «Estudios y ocurrencias sobre la Cuestión de Santiago en el siglo XX. Revisión panorámica», edición de Juan José Cebrián Franco. Compostellanum 48 (1-4): 448-514.

Herbers, Klaus. 2006. Política y veneración de santos en la Península Ibérica. Desarrollo del 'Santiago político'. Pontevedra: Fundación Cultural Rutas del Románico.

Hobsawm, Eric y Terence Ranger. 1983. The invention of tradition. Cambridge: University Press.

Huidobro Serna, Luciano. 1949-1951. Las peregrinaciones jacobeas. Madrid: Publicaciones del Instituto de España.

López Alsina, Fernando. 2013. La ciudad de Santiago de Compostela en la Alta Edad Media. Santiago de Compostela: Consorcio de Santiago y Universidade de Santiago de Compostela.

López y López, Román. 1915. Santiago de Compostela: guía del peregrino y del turista. Santiago de Compostela: Tipografía El Eco Franciscano.

López, Atanasio. 1935. «Descubrimiento del sepulcro del Apóstol Santiago: la estrella refulgente». Galicia: revista gráfica mensual 18: 14-16.

Márquez Villanueva, Francisco. 2004. Santiago, trayectoria de un mito. Barcelona: Edicions Bellaterra.
Mateo Sevilla, Matilde. 1992. El Pórtico de la Gloria en la Inglaterra Victoriana: la invención de una obra maestra. Santiago de Compostela: Museo Nacional de las Peregrinaciones.

Menaca, Marie de. 1995. "Dos problemas diferentes sobre Santiago en España, su predicación y su sepultura». En Actas del Congreso de Estudios Jacobeos, 219-233. Santiago de Compostela: Xunta de Galicia.

Mera Álvarez, Irene. 2003. "La capilla mayor y la cripta apostólica de la catedral de Santiago en la Edad Contemporánea». En El comportamiento de las catedrales españolas: del Barroco a los Historicismos, coordinación de Germán Antonio Ramallo Asensio, 149-158. Murcia: Universidad de Murcia.

Mera Álvarez, Irene. 2011. La catedral de Santiago en la época contemporánea: arte y arquitectura (1833-1923). Santiago de Compostela: Teófilo Edicións e Consorcio de Santiago.

Millán González-Pardo, Isidoro. 1990. «Importantes descubrimientos en el mausoleo del Apóstol Santiago». Peregrino 17: 18-20.

Moralejo Álvarez, Serafín. 1980. «Ars Sacra et sculpture romane monumentale: le trésor et le chantier de Compostelle». Les cahiers de Saint-Michel de Cuxa 11: 230-237.

Otero Túñez, Ramón. 1977. «La Edad Contemporánea». En La catedral de Santiago de Compostela, dirección de Manuel Lucas Álvarez, 379-399. Santiago de Compostela: Caja de Ahorros de Santiago.

Pérez de Urbel, Justo. 1952. "Orígenes del culto de Santiago en España». Hispania Sacra V, 1-34.

Pérez Varela, Ana. 2018. «Una aproximación a la figura del platero compostelano José Losada de Dios (ca. 1817-1887)». En Yngenio e arte: elogio, fama y fortuna de la memoria del artista, edición de María del Mar Alberto Muñoz y Manuel Pérez Sánchez, 675-696. Murcia: Fundación Universitaria Española.

Pérez Varela, Ana. 2019. El platero compostelano Ricardo Martínez Costoya (1859-1927): contexto, vida y obra. Tesis doctoral. Universidade de Santiago de Compostela.

Pombo Rodríguez, Antón. 2001. «O rexurdir do culto xacobeo e da peregrinación durante o pontificado do cardeal Miguel Payá y Rico". En Congreso Internacional de Asociaciones Jacobeas, edición de Antón Pombo Rodríguez, 157-196. A Coruña: Deputación Provincial da Coruña.

Pombo Rodríguez, Antón. 2009. O Cardeal don Miguel Payá y Rico (1811-1891): Bispo de Cuenca, Arcebispo de Compostela e Primado de España. Santiago de Compostela: Consorcio de Santiago Instituto Teolóxico Compostelán.

Portela Pazos, Salustiano. 1953. "Orígenes del culto al Apóstol Santiago en España». Arbor 91-92: 455-471.

Pose Antelo, Xosé Manuel. 1992. La economía y la sociedad compostelanas a finales del siglo XIX. Santiago de Compostela: Universidade de Santiago de Compostela.

Requejo Alonso, Ana Belén. 2005. Los museos eclesiásticos de Galicia. Tesis doctoral. Universidade de Santiago de Compostela.

Rey Castelao, Ofelia. 1993. El voto de Santiago. Claves de un conflicto. Santiago de Compostela: Imprenta Aldecoa.

Rey Castelao, Ofelia. 2006. Los mitos del Apóstol Santiago. Santiago de Compostela: Consorcio de Santiago.

Sánchez Albornoz, Claudio. 1971. «En los albores del Culto Jacobeo». Compostellanum 16: 37-71.

Sánchez Cantón, Francisco Javier. 1956. Opúsculos gallegos sobre BeIlas Artes de los siglos XVII y XVIII. Santiago de Compostela: Bibliófilos Gallegos.

Sánchez Sánchez, Xosé. 2010. A colección López Ferreiro do ArquivoBiblioteca da Catedral de Santiago de Compostela. Santiago de Compostela: Consello da Cultura Galega.

Sentenach, Narciso. 1909. Bosquejo histórico sobre la orfebrería española. Madrid: Imprenta de la Revista de Archivística, Bibliotecas y Museos.

Serrano Martín, Eliseo. 2014. «Silentium facite: El fin de la polémica y el discurso en torno a la Virgen del Pilar en la Edad Moderna». Hispania 248: 687-714. https://doi.org/10.3989/hispania.2014.020

Singul Lorenzo, Francisco Luis. 2004. "Tradicións xacobeas: primeiras noticias sobre a envanxelización do confín do mundo e a tumba de Santiago en Galicia». En Até o confín do mundo: diálogos entre Santiago e o mar, 97-103. Vigo: Museo do Mar de Galicia. 
Suárez Otero, José. 1999. «La catedral de Santiago de Compostela: cien años de arqueología». Codex Aqvilarensis: Cuadernos de investigación del Monasterio de Santa María la Real, 14: 39-71.

Suárez Otero, José. 2001. "As reliquias como esperança: a tumba de Santiago». En Santiago de Compostela, um tempo, um lugar, 165175. Santiago de Compostela: Xunta de Galicia.

Suárez Otero, José. 2003. «Del locus Sancti lacobi al burgo de Compostela». En Historia de la ciudad de Santiago de Compostela, coordinación de Emelindo Portela Silva, 49-77. Santiago de Compostela: Universidad de Santiago de Compostela.

Suárez Otero, José. 2014. Locus lacobi: Orígenes de un santuario de peregrinación. Tesis doctoral. Universidade de Santiago de Compostela.

Taín Guzmán, Miguel, 2006. «El proyecto del canónigo José Vega y Verdugo para el sepulcro del Apóstol de la Catedral de Santiago». En Congresso Internacional do Barroco Ibero-Americano, 596-610. Ouro Preto: C/Arte.

Taín Guzmán, Miguel. 2008. «Prolegómenos de una excavación en tiempos del canónigo José Vega y Verdugo: el mito de la cripta del apóstol Santiago y el retablo del arzobispo Gelmírez». Goya 324: 200-216.

Taín Guzmán, Miguel. 2010. «Permanencia e destrucción do Altar de Xelmírez na Época Moderna», en Compostela e Europa: a historia de Diego Xelmírez, dirección de Manuel Antonio Castiñeiras González, 166-181. Santiago de Compostela: S. A. de Xestión do Plan Xacobeo.

Temperán Villaverde, Elisardo. 2001. «Culto y liturgia en torno al sepulcro que guarda la "memoria" del Apóstol Santiago el Mayor». En El «Codex Calixtinus» en la Europa del siglo XII: música, arte, codicología y liturgia, edición de Juan Carlos Asensio Palacios, 17-37. Madrid: Instituto Nacional de las Artes Escénicas y de la Música.

Torres Rodríguez, Casimiro. 1957. «Arca marmorea». Compostellanum 2: 323-351.

Velasco Gómez, Clodoaldo. 1948. Santiago y España. Madrid: Instituto P. Flórez.

Vidal Rodríguez, Manuel. 1924. La tumba del Apóstol Santiago: ilustrada con cien fotograbados. Santiago de Compostela: Tipografía del Seminario Central.

Villares Paz, Ramón. 1979. «López Ferreiro e a historiografía galega». Grial 66: 425-441.

Villares Paz, Ramón. 2004. "A segunda invención de Santiago». Grial 161: 12-17.

Vives, José. 1956. «Bibliografía. Compostellanum, revista trimestral». Hispania Sacra IX: 473-475.

Yzquierdo Peiró, Ramón. 2017. Los tesoros de la Catedral de Santiago. Santiago de Compostela: Consorcio de Santiago -Teófilo Edicións. 